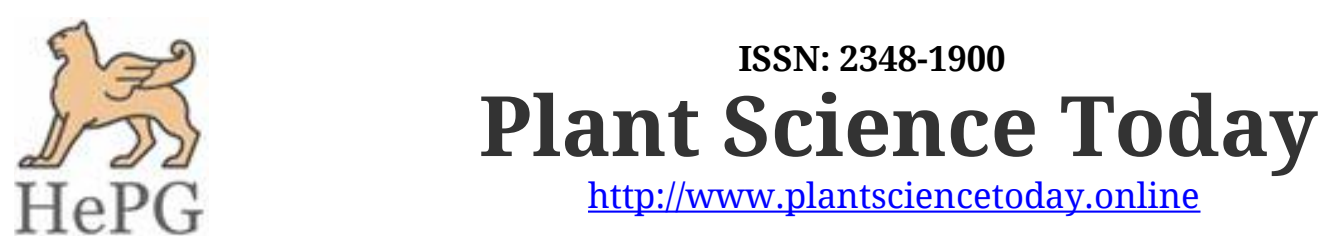

\title{
A review on molecular techniques employed for authentication of Indian medicinal plants
}

\author{
Rubeena Mattummal, Divya Kallingilkalathil Gopi, Erni Bobbili \& Sunil Kumar Koppala Narayana ${ }^{*}$
}

Department, of Pharmacognosy, Siddha Central Research Institute, Chennai 600 106, India

\section{Article history}

Received: 12June 2019

Accepted: 19 August 2019

Published: 01 October 2019

\section{Publisher}

Horizon e-Publishing Group

\section{*Correspondence}

Sunil Kumar Koppala Narayana

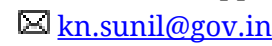

\begin{abstract}
Traditional medical systems are advancing to the level of modern medicines in treatment and preventive aspects. The increased trade in medicinal plants provides income source for herbalists while substitution of rare ingredients with cheaper and more readily available species is misleading the end users. The prime cause of the problems associated with the standardization of medicinal plants is complex composition of herbal drugs used in the form of whole plants, plant parts or extracts. Deliberate adulteration of intended ingredients are posing difficulty in distinguishing the genuine resources. Authentication of medicinal plants by recent molecular techniques is inevitable for herbal drug industries, researchers and academia. Of late, herbal genomics, molecular studies of medicinal plants and powerful next generation sequencing techniques have been emerged to transform the current knowledge. A compilation of various molecular markers used, their efficiency in barcoding for the purpose of accurate authentication of herbal drugs has been attempted in this study. Data were collected from previous literature and online repositories like NCBI, Pubmed etc. There are various molecular techniques that can be exploited for authentication of medicinal plants such as Restriction Fragment Length Polymorphism (RFLP), Random Amplified Polymorphic DNA (RAPD), Amplified Fragment Length Polymorphism (AFLP), Sequence Characterized Amplified Region (SCAR), Selective Amplification of Microsatellite polymorphic loci (SAMPL), Simple Sequence Repeats (SSR), Inter Simple Sequence Repeat (ISSR), DNA barcoding, Next Generation Sequencing Techniques etc. Some of medicinal plants were reported having molecular data useful in plant identification. The genomic data of poly herbal formulations helps for scientific validation and universal recognition. Even though the challenges associated with reprehensibility, primer designing, amplification products of molecular markers and troubles related with DNA isolation and purification, become the major obstacle in front of researchers. It is high time to focus these novel strategies for proper identification to ensure the fidelity of traditional herbal products and there by promoting a step towards the global acceptance of our indigenous medicinal systems.
\end{abstract}

Keywords: Adulteration; RAPD; RFLP; AFLP; SCAR; Plant barcoding

Citation: Mattummal R, Gopi D K, Bobbili E, Narayana S K K. A review on molecular techniques employed for authentication of Indian medicinal plants. Plant Science Today 2019;6(4):465-478. https:// doi.org/10.14719/pst.2019.6.4.58

Copyright: (c) Mattummal et al (2019). This is an open-access article distributed under the terms of the Creative Commons Attribution License, which permits unrestricted use, distribution, and reproduction in any medium, provided the original author and source are credited (https://creativecommons.org/licenses/by/4.0/).

Indexing: Plant Science Today is covered by Scopus, Web of Science, BIOSIS Previews, ESCI, CAS, AGRIS, CABI, Google Scholar, etc. Full list at http://www.plantsciencetoday.online

\section{Introduction}

Indian flora is enriched with 3000 to 3500 species of medicinal plants used in traditional systems of medicine in which 2500 species are endemic (1).
India is being blessed with its own systems of medicine originated in ancient times in connection with particular culture and geographical locations which are based mostly on the indigenous herbal plants available. Since the plants having different 
names locally the chance of misidentification is more and will affect the quality of it. In this regard plants are to be authenticated by eminent botanists if in fresh form or by pharmacognostical and by chemical finger printing methods when in dried form. Conventional macro-microscopic examinations and other quality assurance tools do not aid in critically distinguishing raw materials derived from closely related species, adulterants or substitutes (2). According to the WHO general guidelines for methodologies on research and evaluation of traditional medicines, first step in assuring quality, safety and efficacy of traditional medicines is correct identification (3).

Standardization of medicinal plants is necessary for its authentication resulting in botanical identity. The quality control and identification of herbal plants can be done through the analysis of well-defined marker compounds. However, in many herbal species the chemical composition of the plant changes with the external environment and processing conditions, which lowers the reliability of these authentication methods (4). Molecular techniques helps to overcome all these drawbacks associated with other methods. Now some of the research centers in India have started molecular profiling to focus on the genetic information of both fauna and floras. The researchers in India have tried to spot convinced easy and modern molecular biology technologies that can be employed in order to identify the function of the genes and their higher usability of ancient knowledge of medicinal plants to treat the human diseases by identifying the effect of the bioactive compound(s) in medicinal plant(s) to treat patients and to enhance conventional treatment for better patient outcome (5). As India is diversified with its resource of biodiversity, so many molecular studies and genetic data has been recorded as part of conservation and to manage the diversity as well as keeping awareness to the public about our vast precious bio-resources. Owing to the large scale inventorization of biodiversity conservation DNA barcoding of tropical trees of India were done using ITS and trnH-psbA and considered to be highly successful (6). DNA barcoding has been used to discriminate at species level and it is helped to trace out a new cryptic grass species in an ethnobotanic study by the hill tribes of the Western Ghats in South India (7).

This review provides insight on need for molecular authentication of medicinal plants to improve the quality, safety and efficacy of the drugs and also gives a brief account of the most commonly used DNA-based technologies (RAPD, RFLP, AFLP, SCAR, sequencing, microarrays, next generation sequencing techniques) including suitable examples of South Indian medicinal plants.

\section{Data aquisition}

Extensive literature review was carried out by refereeing various books, monographs, articles and journals along with online portals (NCBI, PUBMED) pertaining to medicinal plants and their recent molecular studies.

\section{Results}

\section{Authentication of medicinal plants by molecular markers}

DNA markers which are based on distinct genetic organization are having a greater advantage over other marker systems. These markers are not tissue specific and thus can be detected at any stage of plant development. As the information generated by this technology can be easily automated, it gives accurate and efficient methods which will be cheaper and more authentic than the phenotypic and chemical markers (8).

A genetic marker or DNA markers are the unique DNA sequences which can be used in DNA hybridization, PCR or restriction mapping experiments to identify target sequence. It gives the direct reflection of genotype (9).

\section{Molecular markers used for authentication}

DNA hybridization based markers (Non PCR based markers): It is widely used method for identification purposes. The limitation of this approach is that it needs high quantity of DNA and use of radio labeled probes for experiments (9).

\section{RFLP (Restriction Fragment Length Polymorphism)}

It is a molecular marker used for the separation and identification of desired fragments of DNA using restriction enzymes. It is the first used technology employed for detection of polymorphism based on DNA differences. It involves the isolation of DNA, itsdigestion by restriction enzymes and the fragments separation by gel electrophoresis. The desired fragment is detected by using labeled probes. The main limitation of this technique is, it requires large amount of sample DNA and it is time consuming and labor intensive (9).

Markers based on PCR amplification: PCR technique is used for the amplification of desired DNA sequences. It requires low quantity of DNA for the experiments (9).

\section{RAPD (Random Amplification of polymorphic DNA)}

It is a non-locus specific DNA marker used for the amplification of desired DNA fragments for the detection of polymorphisms based on PCR amplification using short synthetic primers. The amplified products are separated by electrophoresis and detected. It is very quick and easy technique and there is no need of sequence 
data for primer construction. The RAPD have high genomic abundance and is found randomly distributed throughout the genome but it is low reproducible and unsuitable marker for comparison of similar species (9).

\section{AFLP (Amplified Fragment Length Polymorphism)}

This is also a non-locus specific DNA marker employed for identification purposes which involves detection of genomic restriction fragments and can be used for DNAs of any origin or complexity. AFLP is based on the principle of generation of DNA fragments using restriction enzymes and oligonucleotide adaptors (or linkers), and their amplification by PCR. Thus, this technique combines the usefulness of restriction digestion and PCR. It is very sensitive and reproducible (9).

\section{SCAR (Sequence characterized amplified region)}

In this technique 18 to 25 base pair primers, based on a unique RAPD sequences are used. It is possible to perform SCAR under high stringent reaction conditions enhancing its specificity and stability (8). These primers are usually much longer than RAPD primers and allow for PCR analysis; therefore, their amplicons are more reproducible and easily recognized (10).

\section{Microsatellite based molecular markers}

Some of most popularly used microsatellite markers are discussed below:

\section{SSR (Simple Sequence Repeats) markers}

These are the most efficient markers of 2 to 5 DNA base pairs and are a type of variable number tandem repeats (VNTRs). SSRs are co-dominant molecular markers that distinguish homozygotic and hetrozygotic individuals and also possess a large number of alleles. In fact, the use of single SSR marker may not provide authentic information hence we have to use different SSR markers for reliable and accurate differentiation of plants (11).

\section{ISSR (Inter Simple Sequence Repeat) markers}

PCR based technique reported by Zietkiewicz 1994, (12) involves amplification of DNA segments between two identical microsatellite repeat regions oriented in opposite direction using primers designed from microsatellite core regions. The technique uses microsatellite primers, usually 16 to 25 base pairs long. ISSR technique is simple, quick and less costly like the RAPD technique. ISSR markers have high reproducibility than RAPD primers due to the longer primer length (13).

\section{SAMPL (Selective Amplification Microsatellite polymorphic loci) markers}

This is a microsatellite-based dominant marker system which is a modification of AFLP techniques
(14). DNA is prepared in the same way as for an AFLP assay, allowing the use of the same preamplified samples, but changing the primer used in the selective amplification for a microsatellite sequence (15).

\section{DNA barcoding}

This involves the application of short DNA sequences for identification of organisms. In DNA barcoding the main focus is to find out a universal DNA sequence that must a balance of conserved sequence as well as harbor enough diversity in order to differentiate organisms (8). Many chloroplast genomic regions (rbcL, matK, trnH-psbA, trnL-F, rpl36-rps8, ITS and 5S rRNA) have been evaluated in plant systems by- "The Consortium for the Barcode of Life Plant Working Group (CBOL)"(16) for making barcodes for better identification of plants. Cameron and Chase 1999, (17) showed less species discriminating ability with rbcl and matK when very close taxa are concerned. Hence, Li et. al., 2011, (18) included nuclear ITS to the combination matK + rbcL with the aim to have better discriminating ability in closely related species.

\section{Next generation sequencing technologies}

It is a well advanced and powerful DNA sequencing method for whole genome representation, which aids in complete characterization and analysis of genetic and genomic resources. Most NGS methods are based on polymerase chain reaction (PCR) amplification of platform-specific DNA fragment libraries, which are then sequenced (19). This new technology will transform the biological world to be astonished one which we cannot even imagine. This technology can bring vast changes in the medical field since it is able to perceive the all aspects of genomic alterations which lead to diseases like cancer. NGS provides platforms for the study of exome, transcriptome, epigenome and whole genome. It needs time investment, advanced laboratory facilities and involves computational analysis and bioinformatics studies.

These methods can mainly divided to three types: sequencing by synthesis, sequencing by ligation, and single-molecule sequencing.

Sequencing by synthesis: Here, the appropriate DNA fragment is ligated to adaptor sequences and amplified to improve the fluorescent or chemical signal. Templates are immobilized in preparation for flow-cell cycles after separation (20).

Sequencing by ligation: Different lengths of florescent labelled oligonucleotide probes are used in this method. Anchor sequences which used as primers help for hybridization and DNA ligase in the flow cell attach probes to the primer and template. The incorporated probe is determined by fluorescence imaging (20). 


\section{Single-molecule sequencing:}

It is known as third generation sequencing which overcomes the difficulties of other NGS technologies. This method employs use of single nucleic acid molecule for DNA sequencing which excludes the DNA template amplification. Here, the incorporation of nucleotide is detected as a signal by chemi-luminescence. This technique is more advanced and having high multiplex ability (20). Various Next-Generation Sequencing (NGS) Platforms used are listed in Table $1(20,21)$.

\section{Plant barcoding system}

Molecular taxonomists now envisage cataloging all living species on earth using so-called DNA barcodes, the nucleotide sequence of a short DNA fragment (22-24). In the past two decades the

\section{Role of Next generation Technologies in transforming the knowledge of biological world}

NGS technologies have emerged as a flagging leader in the modern era of scientific discoveries. Every branch of biological science has become the vital part of genomics since these methods have paved the most easily, accessible and cost effective genome sequencing. The researchers are discovering new approaches and seeking novel interdisciplinary branches for the application of NGS. Few studies are reported in plants in which NGS technologies applied for molecular characterization. In a study (30), the authenticity of NGS for developing SSR in plants via their work on Cranberry was convinced and the authors reviewed 95 other studies for the same by Sanger,

Table 1. Various Next-Generation Sequencing (NGS) Platforms (20, 21)

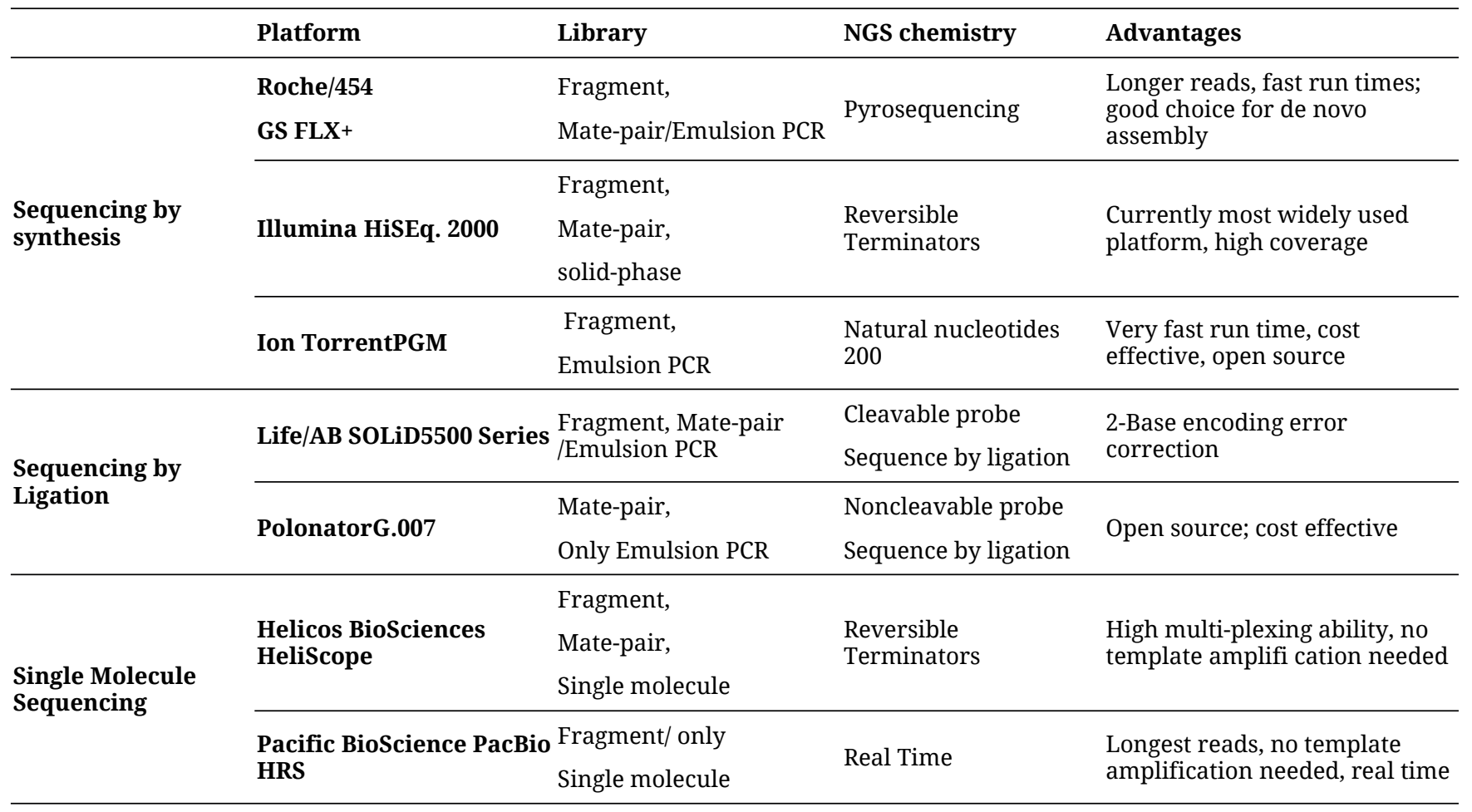

molecular investigations of systematic problems have progressed from uncommon curiosities to a standard means of elucidating phylogenetic history (25). The use of genome-based methods for the authentication of medicinal plants should be seen in the context of plant phylogenetic studies and a general effort aimed at barcoding of all plants $(26,27)$. A preliminary system for DNA barcoding herbal materials has been established based on a two-locus combination of ITS $2+p s b A-$ trnH barcodes. There are 78,847 sequences belonging to 23,262 species in the system, which include more than $95 \%$ of crude herbal drugs in pharmacopeia, such as those of China, Japan, Korea, India, USA and Europe (28). Although there are no specified DNA sequences for plant barcoding, the psbA-trnH spacer region has been tested widely and found to be effective (29).
Illumina and 454 technologies. In the case of species that do not having a reference genome, the NGS-based SNP discovery is very challenging (20). There are studies where usage of four short read alignment tools (Maq, BowTie, Novoalign, and SOAP2) using their novel strategy called coveragebased consensus calling (CbCC) for SNP discovery as a case study in chickpea, Cicer arietienum L., a crop lacking a reference genome. They found Maq as effective technique (31).

\section{Application of DNA-based authentication in medicinal plants}

Several plants are being distinguished with the help of this new system of identification. Two species of the parasite Cuscuta (C. reflexa and $C$. chinensis) have been distinguished with primers OPC-1, OPC-02, OPC-03, OPC-04, OPC-05, OPC-06, 
OPC-07 and OPC-08, $(32,33)$ while characterizing Clitoria ternatea at inter-zonal level identified complete monomorphism with primer OPN-02 which makes OPN-02 a good choice for the identification of this herb. Molecular characterization of Convolvulus pluricaulis revealed that primer OPN-09 is the species specific primer for the herb (8). A common band of $2.2 \mathrm{~kb}$ amplified by Primer OPN-05 was found when different accessions of Evolvulus alsinoides were studied through RAPD analysis (34). The roots of Cissampelos pareira var. hirsuta (Buch.-Ham. ex DC.) Forman) generally named as Patha in India is substituted with two other species, viz., Cyclea peltata (Lam.) Hook.f. \& Thomson and Stephania japonica (Thunb.) Miers. ISSR profiles (35) distinguished genuine raw drug of Patha from its substitutes/adulterants to guarantee the quality and legitimacy of this drug in the market (8).

Usage of rbcL sequences alone to make assignments to species (or species groups) for $85 \%$ of all root samples examined, permitting a detailed examination of the ecological factors that contributed to the subterranean spatial organization of plant diversity in an old-field community (36). Likewise, DNA barcoding can provide identification where material has been processed in one way or another, such as analyzing the diet of herbivores $(37,38)$, food products (39), or the components of herbal medicines (40). matK DNA barcodes are also used to highlight misidentified plant species in herbal supplements (41). There are reports on the usage of DNA barcoding as an efficient tool for tracing medicinal plant and aromatic plants to provide a safer food supplement for consumers (42). DNA metabarcoding has been applied to assess the quality and validate herbal drugs in the industrial context (43). A novel nanoparticle- DNA barcoding hybrid system named NanoTracer has also been used which helps for hasty and molecular level invention of any food and herbal materials (44).

The development of bioinformatics provides a broad spectrum for combining unlinked and scattered genomic data of medicinal plants and facilitates the identification of plant sources and discovery of new drugs for future therapeutics (45). The development and application of toxicogenomics for finding the drug interaction and toxic chemicals in the herbs helped tracing adulterants in Chinese herbal medicines (46). There are reports on the use of NGS in phylogenetic analysis of two lineages of monocots, the Asparagales and the grasses, using Illumina data (80 - 120-bp reads) (47).

\section{Emergence of herbal Genomics}

The medicinal value of each plant is the output of the secondary metabolites produced in different pathways. These pathways need to be explored to know the potential bioactivities of the plants and also for the new drug discovery. Hence the whole nuclear and chloroplast genomes needed to be sequenced to understand these metabolic pathways. An attempt for the analysis of genome sequencing of various medicinal plants and their functional genomics is initiated by "Herb Genome Programme" (48). Genomic information, together with transcriptomic, proteomic and metabolomic data, can therefore be used to predict the secondary metabolic pathways of herbs (49). The genomes of some commonly used medicinal mushroom Ganoderma lucidum and herbs Salvia miltiorrhiza Bunge and Catharanthus roseus (L.) G. Don have already sequenced and they emerged as valuable models for studying the genetic and metabolic activities of herbs (50-52). The whole nuclear and chloroplast genomes of holy basil (Ocimum sanctum L.) have been sequenced and analyzed for the expression of various metabolite pathways which helps to relate the biosynthetic pathways of related species (53). The whole genome data of Azadirachta indica A. Juss., Ziziphus jujuba Mill., Gelsemium sempervirens (L.) J.St.-Hil. Camptotheca acuminata Decne. Calotropis gigantea (L.) Dryand. are also released recently to the herbal genomics (54-57). Molecular studies have been used in the identification of several other medicinal plants (Table 2).

\section{Application in identification of polyherbal formulations}

The traditional medicines and the herbal products have attracted global attention and the commercial interest augmented the encouragement for adulteration and substitution in the herbal market. This has prompted and challenging the herbal pharmacovigilance to build up novel techniques for the complete assessment and monitoring of herbal products. A study reported DNA metabarcoding to authenticate seventy-nine Ayurvedic herbal products sold as tablets, capsules, powders, and extracts were randomly purchased via e-commerce and pharmacies across Europe (186). The low level ingredient fidelity in their analysis raises concerns of fidelity and quality of herbal drugs and highlights the necessity for quality control of marketed herbal products and shows DNA metabarcoding as an effective analytical approach to authenticate complex polyherbal formulations. In an another study (180), RAPD technique was employed for determination of the components in an Ayurvedic herbal prescription, "Rasayana Churna" for the simultaneous identification and quantification of Tinospora cordifolia, Emblica officinalis and Tribulus terestris in Rasayanachurna. Primer OPC-6 clearly differentiates all components of Rasayanachurna (180). This has proved as an efficient, precise and sensitive method for identifying components for Churnas and will contribute significantly in quality control. There are reports that analyzed the Chinese herbal formulation "Ruyi Jinhuang" composed of nearly 10 ingredient drugs based on 
high-throughput sequencing and DNA barcoding for authentication of ingredients and identification of adulterants and toxic compounds (187). Their findings established an effective approach for monitoring the biological composition of traditional Chinese medicines based on highthroughput sequencing and DNA barcoding. Realtime PCR was included to validate the accuracy of identification. This study demonstrates the application of high-throughput sequencing combined with real-time PCR to detect the biological and toxic ingredients in herbal preparations (187).

\section{Challenges and constrains}

Isolation of quality DNA is essential step in molecular characterization even though a particular molecular marker is selected. There are many issues reported for the isolation of DNA from plants. Isolated DNA showed colored substances, polysaccharides and phenolic compounds (188-89). The best method for the extraction and purification of DNA from a particular plant or drug sample needs to be established empirically. Techen and colleagues 2006, (190) showed that the success of PCR was dependent on both the type of source material (raw plants, herbal teas, tablets, capsules) as well as the specific brand of commercial DNA extraction kit used.

Sequence-based analyses sometimes fail to distinguish between species because of the significant similarity between their DNA sequences in the amplified region. RAPD primers are able to distinguish taxa below the species level (191), because RAPD analysis reflects both coding and non-coding regions of the genome (209). However, some of the problems with RAPD are related to reproducibility, designing appropriate primers and amplification of RAPD-PCR products. PCR conditions constitute one of the crucial factors for obtaining amplified products, especially for plants (192). Even though ISSR markers do have more value compared to RAPDs, the marker has the reproducibility issues and moreover it is a co dominant marker. It has been found that DNA barcoding fail to distinguish recently diverged species (193). In the case of SCAR technology it needs prior sequence data for designing primers. Primer designing in Loop Mediated Isothermal Amplification (LAMP) technology is complex; a minimum of two primer pairs is required to identify six different regions of target gene/DNA sequence (8).

Identification of polyherbal formulations is still a challenging task due to the difficulties associated with complex DNA isolation procedures. In addition to the degradation of DNA while processing or preparation of formulation adversely affects the sequencing. Due to the lack of strict regulatory controls, improper manufacturing process, this popular herbal product needs more scientific validation.
Even though a universal barcode has been established for plant species identification it is found to be not applicable for most of trees and herbs and which is exemplified while working on Dendrobium species (194). A case study with Indian Berberry species also confirmed the nonapplicability of universal barcode when work with complex plant groups (195). The next generation technologies can circumvent all the quandaries of other molecular techniques.

\section{Discussion}

Medicinal plants represent the valuable source of traditional and modern medicine. The commercialization of raw drug mate rials has led to the increased use of adulterants and substitutes in the trade of medicinal plants. The gradual deterioration in the knowledge about the identification of medicinal plants has led to many misinterpretations and has put many herbal drugs in controversial position. The international trade of herbal products is one of the major forces in the global economy with increased demand in both developed and developing countries. In addition to ambiguity in nomenclature, the crude drugs sold in the market are adulterated or substituted by quite unrelated plant materials. Thus, authentication of botanical source of plant from which the raw drugs are obtained for research or medicinal use is a necessity to accomplish satisfactory results and also to sustain the efficacy and therapeutic property of the preparations in which these plants are used. We have tried to present a comprehensive review on strategies related to identification of medicinal plants used in Indian medicinal system based on the various DNA markers. DNA based authentication of medicinal plants can be useful as a tool for quality control and safety monitoring of herbal pharmaceuticals and neutraceuticals and will significantly add to the medical potential of herbal products (8).

The greatest drawbacks in support and promotion of herbal products are adulteration of their market samples. Due to this adulteration and altered efficacy, the faith in crude drug promotion has declined (196). One of the encumbrances in the approval of herbal formulations is the lack of standardization and quality control profiles. Owing to the complex nature and inherent variability of the chemical constituents of plantbased drugs, it is difficult to establish quality control parameters using phytochemical tools (197). The pitfalls associated with the common conventional pharmacognosy methods like macromicroscopic examination and phytochemical analysis have insisted researchers to the exploration of ultimate solutions for authentication of herbs and formulations (198). Expected chemicals in the herbal plant targeted 
for medicinal use could vary with the genomic or environmental variability of the species (199).

DNA-based techniques have been widely used for authentication of plant species of medicinal importance. This is especially useful in case of those that are frequently substituted or adulterated with other species or varieties that are morphologically and/or phytochemically indistinguishable. DNA markers use nucleotide sequences to identify species; it takes preference over the other two markers being not age dependent, tissue specific and having a higher discriminating power. Therefore, characterization of plants with such markers is an ideal approach for identification of medicinal plant species and populations/varieties of the same species. DNA markers have superiority in identifying medicinal plants compared to other markers. According to one study on the various DNA markers, LAMP, SCAR and DNA barcoding are ideal for authentication (8). DNA markers are very reliable for informative polymorphisms and as the genetic composition are unique for each species and are not affected by age, any physiological conditions and as well as environmental conditions (200). British and Chinese pharmacopoeia has already started including modern DNA-based details to distinguish herbs (201-203). It is high time to focus the molecular details of medicinal plants used in Indian systems of medicines for the proper identification. Indian research institutes on traditional systems coming under AYUSH also should implement these details in their pharmacopoeia. A reference library of DNA markers of traditional medicinal plants is surely required and should be established. The availability of certified taxonomic specimens in herbaria and raw drug samples in museums are indeed required for the unambiguous authentication through final visual assessment and analysis. Now the NGS technologies have proven its application in plant science context also, it is essential to emphasis on this advanced tool for the comprehensive genomic analysis and genetic conservation of Indian medicinal plants. NGS methods differ in read length, the types and prevalence of errors and the number of reads created per run; different approaches are needed to deal with the data in terms of quality control, assembly, and analysis. This presents a major challenge in terms of computational resources, innovation and application (20).

\section{Conclusion}

This review focused the need of application of novel strategies for authentication and identification of both raw drugs and final herbal products to ensure the quality, efficacy and fidelity of the herbal system. The pharmacopeias should include the new techniques of identification methods which are accompanied by the modern science and technology developments. Even though we are having these many molecular data of medicinal plants for authentication which is mainly focused on molecular code of leaves, the correct identification is possible only when the mentioned part of concerned drug is barcoded. The emergence of herbal genomics and NGS technologies will open a wide spectrum of global approval and consistency to these medicinal plants and their products.

\section{Acknowledgement}

The authors extend their heartfelt thanks to Prof. Dr. K. Kanakavalli, Director General, Central Council for Research in Siddha, Chennai and Dr. P. Sathiyarajeswaran, Assistant Director (Siddha) and In-charge, Siddha Central Research Institute, Chennai for the support.

\section{Competing Interests}

The authors declare that they have no competing interests.

\section{Authors' contribution}

RM contributed to the intellectual content, conceptualization of the topic, designing, data acquisition and interpreting analysis for the manuscript, DKG contributed literature review and data tabulation, EB contributed in data compilation, SKKN contributed manuscript review and manuscript editing and revised to final format.

\section{References}

1. Daniels RR. Taxonomic uncertainties and conservation assessment of the Western Ghats. Curr Sci. 1997;73(2):169-70.

2. Balasubramani SP, Goraya GS, Venkatasubramanian P. Development of ITS sequence-based markers to distinguish Berberis aristata DC. from B. lyceum Royle and B. asiatica Roxb. 3 Biotech. 2011;(1):11-19. https://doi.org/10.1007/s13205-010-0001-5

3. WHO traditional medicine strategy. Geneva: World Health Organization Geneva; 2002.

4. Chen S, Yao H, Han J, Liu C, Song J, Shi L, et. al., Validation of the ITS2 region as a novel DNA barcode for identifying medicinal plant species. PLoS One. 2010;5(1):8613.

https://doi.org/10.1371/journal.pone.0008613

5. Vaidyanathan V, Naidu V, Jabed A, Tran K, Kallingappa $\mathrm{P}$, Kao CH, et. al. Modern molecular biology technologies and higher usability of ancient knowledge of medicinal plants for treatment of human diseases. In Plant and Human Health, Volume 2 2019; pp. 173-205. Springer, Cham. https://doi.org/10.1007/978-3-030-03344-6 7

6. Tripathi AM, Tyagi A, Kumar A, Singh A, Singh S, Chaudhary LB, Roy S. The internal transcribed spacer (ITS) region and trnhH-psbA are suitable candidate loci for DNA barcoding of tropical tree species of India. PLoS 
One. 2013;8(2):e57934 https://doi.org/10.1371/journal.pone.0057934

7. Ragupathy S, Newmaster SG, Murugesan MVB. DNA barcoding discriminates a new cryptic grass species revealed in an ethnobotany study by the hill tribes of the Western Ghats in southern India. Mol Ecol Resour. 2009;19:164-71. 0998.2009.02641.x https://doi.org/10.1111/j.1755-

8. Ganie SH, Upadhyay $\mathrm{P}$, Das S, Sharma MP Authentication of medicinal plants by DNA markers. Plant Gene. 2015;4:83-99. https://doi.org/10.1016/j.plgene.2015.10.002

9. Chawla H. Introduction to Plant Biotechnology (3/e). CRC Press; https://doi.org/10.1201/9781315275369-1

10. Zhou J, Wang W, Liu M, Liu Z. Molecular authentication of the traditional medicinal plant Peucedanum praeruptorum and its substitutes and adulterants by DNA -barcoding technique. Pharmacogn Mag. 2014;10: 385-90. https://doi.org/10.4103/0973-1296.141754

11. Warburton ML, Zianchun X, Crossa J, Frnaco J, Melchinger AE, Frisch M, et. al., Genetic characterization of CIMMYT inbred maize lines and open pollinated populations using large scale fingerprinting methods. Crop Sci. 2002;42:1832-40. https://doi.org/10.2135/cropsci2002.1832

12. Zietkiewicz E, Rafalski A, Labuda D. Genome fingerprinting by simple sequence repeats (SSR)anchored PCR amplification. Genomics. 1994;20: 176183. https://doi.org/10.1006/geno.1994.1151

13. Vijayan K. Inter simple sequence repeats (ISSR) polymorphism and its application in mulberry genome analysis. Int J Indust Entomol. 2005;10(2):79-86.

14. Rakoczy-Trojanowska M, Bolibok H. Characteristics and a comparison of three classes of microsatellite-based markers and their application in plants. Cell Mol Biol Lett. 2004;9(2):221-38.

15. Morgante M, Vogel JM, inventors; EI du Pont de Nemours and Co, assignee. Compound microsatellite primers for the detection of genetic polymorphisms. United States patent US 5,955,276. 1999.

16. CBOL. Plant working group a DNA barcode for land plants. Proc Natl Acad Sci USA. 2009;106:12794-97.

17. Cameron, KM, Chase MW. Phylogenetic relationships of Pogoniinae (Vanilloideae, orchidaceae): an herbaceous example of the eastern North America-eastern Asia phytogeographic disjunction. Journal of Plant Research.1999;112:317-29. https://doi.org/10.1007/PL00013873

18. Li XK, Wang B, Han RC, Zheng YC, Yin $\mathrm{HB}, \mathrm{Xu}$ L, et. al., Identification of medicinal plant Schisandra chinensis using a potential DNA barcode ITS2. Acta Societatis Botanicorum Poloniae. 2013;82(4):283-88. https://doi.org/ 10.5586/asbp.2013.032

19. Daniels M, Goh F, Wright CM, Sriram KB, Relan V, Clarke $\mathrm{BE}$, et. al., Whole genome sequencing for lung cancer. Journal of thoracic disease. 2012;4(2):155.

20. Egan AN, Schlueter J, Spooner DM. Applications of nextgeneration sequencing in plant biology. Am J Bot. 2012;99(2):175-85. https://doi.org/10.3732/ajb.1200020

21. Metzker ML. Sequencing technologies - The next generation. Nature Reviews Genetics. 2010;11 : $31-46$ https://doi.org/10.1038/nrg2626
22. Hebert PDN, Cywinska A, Ball SL, deWaard JR. Biological identification through DNA barcodes. Proc R Soc Lond B Biol Sci. 2003;270:313-21. https://doi.org/10.1098/rspb.2002.2218

23. Savolainen V, Cowan RS, Vogler AP, Roderick GK, Lane R.Towards writing the encyclopedia of life: an introductin to DNA barcoding. Philos Trans R Soc Lond B Biol Sci. 2005;360:1805-11. https://doi.org/10.1098/rstb.2005.1730

24. Ratnasingham S, Hebert PDN.BOLD: the barcode of life data system (www.barcodinglife.org). Mol Ecol Notes.2007;7:355-64. $\quad$ https://doi.org/10.1111/j.1471$\underline{\text { 8286.2007.01678.x }}$

25. Hillis DM. Molecular versus morphological approaches to systematics. Annu Rev Ecol Syst. 1987 Nov;18(1):23-42. https://doi.org/10.1146/annurev.es.18.110187.000323

26. Kress WJ, Wurdack KJ, Zimmer EA, Weigt LA, Janzen DH. Use of DNA barcodes to identify flowering plants. Proc Natl Acad Sci USA. 2005;102: 8369-74. https://doi.org/10.1073/pnas.0503123102

27. Newmaster SG, Fazekas AJ, Ragupathy S.DNA barcoding in land plants: evaluation of rbcL in a multigene tiered approach. Can J Bot/Rev Can Bot. 2006;84: 335-41. https:// doi.org/10.1139/b06-047

28. Chen S, Pang X, Song J, Shi L, Yao H, Han J, Leon C. A renaissance in herbal medicine identification: from morphology to DNA. Biotechnology Advances. 2014;32(7):1237-44. https://doi.org/10.1016/j.biotechadv.2014.07.004

29. Hao DC, Chen SL, Xiao PG. Authentication of medicinal plants based on molecular biology and genomics. Pharma Biotechnol. 2009;16:490-4.

30. Khan S, Mirza KJ, Abdin MZ. Development of RAPD markers for authentication of medicinal plant Cuscuta reflexa. EurAsia J BioSci. 2010;4:1-7. https://doi.org/10.5053/ejobios.2010.4.0.1

31. Azam S, Thakur V, Ruperao P, Shah T, Balaji J, et al. Coverage-based consensus calling ( $\mathrm{CbCC}$ ) of short sequence reads and comparison of $\mathrm{CbCC}$ results for the identifi cation of SNPs in chickpea (Cicer arietinum; Fabaceae), a crop species without a reference genome. Am J Bot. 2012;99:186-92. https://doi.org/10.3732/ajb.1100419

32. Zalapa JE, Cuevas H, Zhu H, Steffan S, Senalik D, Zeldin E, et. al. Using next-generation sequencing approaches to isolate simple sequence repeat (SSR) loci in the plant sciences. Am J Bot. 2012;99(2):193-208. https://doi.org/10.3732/ajb.1100394

33. Ali Z, Ganie SH, Narula A, Sharma MP, Srivastava PS. Intra-specific genetic diversity and chemical profiling of different accessions of Clitoria ternatea L. Ind Crop Prod. 2013;43,768-773. https://doi.org/10.1016/j.indcrop.2012.07.070

34. Ganie SH, Sharma MP. Molecular and chemical profiling of different populations of Evolvulus alsinoides (L.) L. International Journal of Agriculture and Crop Sciences. 2014;7:1322-31.

35. Vijayan D, Cheethaparambil A, Pillai GS, Balachandran I. Molecular authentication of Cissampelos pareira L. var. hirsuta (Buch.-Ham. ex DC.) Forman, the genuine source plant of ayurvedic raw drug 'Patha', and its other source plants by ISSR markers. Biotech. 2014;4:559-62. https://doi.org/10.1007/s13205-013-0183-8 
36. Kesanakurthi RP, Fazekas AJ, Burgess KS, Percy DM, Newmaster SG, et. al., Spatial patterns of plant diversity below ground as revealed by DNA barcoding. Molecular Ecology. https://doi.org/10.1111/j.1365-294X.2010.04989.x

37. Staudacher K, Wallinger C, Schallhart N, Traugott M. Detecting ingested plant DNA in soil-living insect larvae. Soil Biol Biochem. 201;43:346-50. https://doi.org/10.1016/j.soilbio.2010.10.022

38. Stech M, Kolvoort E, Loonen MJJE, Vrieling K, Kruijer JD. Bryophyte DNA sequences from faeces of an arctic herbivore, barnacle goose (Brantaleucopsis). Mol Ecol Resour. 2011;11:404-08. https://doi.org/10.1111/j.17550998.2010.02938.x

39. Jaakola L, Suokas M, Ha"ggman H. Novel approaches based on DNA barcoding and high-resolution melting of amplicons for authenticity analyses of berry species. Food Chemistry. 2010;123:494-500. https://doi.org/10.1016/j.foodchem.2010.04.069

40. Srirama R, Senthilkumar U, Sreejayan N, Ravikanth G, Gurumurthy BR, et. al., Assessing species admixtures in raw drug trade of Phyllanthus, a hepato-protective plant using molecular tools. J Ethnopharmacol. 2010;130: 20815. https://doi.org/10.1016/j.jep.2010.04.042

41. Harmon L. Rare flowers and common herbal supplements get unmasked with plant DNA barcoding (reporting unpublished data of Damon Little and David Baker). Scientific American Observations. 2010. Available: $\quad \underline{\mathrm{http}}$ ://www.scientificamerican.com blog/post.cfm?id=rare-flowers-and-commonherbalsupp-2010-04-18

42. Frigerio J, Gorini T, Galimberti A, Bruni I, Tommasi N, Mezzasalma V, Labra M. DNA barcoding to trace Medicinal and Aromatic Plants from the field to the food supplement. J Appl Bot Food Qual. 2019;92:33-38.

43. Sgamma T, Lockie-Williams C, Kreuzer M, Williams S, Scheyhing U, Koch E, et. al., DNA barcoding for industrial quality assurance. Planta Med. 2017;83(14/15), 1117-29. https://doi.org/10.1055/s-0043-113448

44. Valentini P, Galimberti A, Mezzasalma V, DeMattia F, Casiraghi M, Labra M, et. al., DNA barcoding meets nanotechno-logy: Development of a Universal Colorimetric Test for Food Authen-tication. Angew Chem Int Ed Engl2017;56(28), 8094-98. https://doi.org/10.1002/anie.201702120

45. Sharma V, Sarkar IN. Bioinformatics opportunities for identification and study of medicinal plants. Briefings in bioinformatics. https://doi.org/10.1093/bib/bbs021

46. Youns M, Hoheisel JD, Efferth T. Toxicogenomics for the prediction of toxicity related to herbs from traditional Chinese medicine. Planta Med. $2010 ; 76: 2019-25$. https:// doi.org/10.1055/s-0030-1250432

47. Steele PR, Hertweck KL, Mayfield D, McKain MR, Leebens-Mack J, Pires JC. Quality and quantity of data recovered from massively parallel sequencing: examples in Asparagales and Poaceae. Am J Bot. 2012;99(2):330-48. https://doi.org/10.3732/ajb.1100491

48. ChenS, Song J, Sun C, Xu, J, Zhu Y, Verpoorte R, et. al., genomics: examining the biology of traditional medicines. Science. 2015;347:527-29.

49. Chakraborty P. Herbal genomics as tools for dissecting new metabolic pathways of unexplored medicinal plants and drug discovery. Biochim Open. 2018;6:9-16. https://doi.org/10.1016/j.biopen.2017.12.003

50. Chen S, Xu J, Liu C. Genome sequence of the model medicinal mushroom Ganoderma lucidum. Nat
Commun.

2012;3:913-22.

https://doi.org/10.1038/ncomms1923

51. Giddings LA. A stereo selective hydroxylation step of alkaloid biosynthesis by a unique cytochrome P450 in Catharanthus roseus. Journal of Biological Chemistry. 2011;286:16751-57. https://doi.org/10.1074/jbc.M111.225383

52. Rastogi S, Kalra A, Gupta V. Unravelling the genome of Holy basil an incomparable "elixir of life" of traditional Indian medicine. BMC Genomics. 2015;16:413-31. https:// doi.org/10.1186/s12864-015-1640-Z

53. Shivaraj Y, Govind S, Jogaiah S, Sannaningaiah D. Functional analysis of medicinal plants using system biology approaches. International Journal of Pharmacy and Pharmaceutical Sciences.2015;7:41-43.

54. Li $\mathrm{Y}, \mathrm{Xu}, \mathrm{C}, \mathrm{X}$. Lin De $\mathrm{X}$. De novo assembly and characterization of the fruit transcriptome of Chinese Jujuba (Zizipus jujuba Mill) using 454 pyrosequencing and the development of novel trinucleotide SSR markers. PLoS One. 2014. https://doi.org/10.1371/journals.Pone.0106438

55. Franke J, Kim J, Hamilton JP, Zhao D, Pham GM, WiegertRininger $\mathrm{K}$, et. al., Gene discovery in Gelsemium highlights conserved gene clusters in monoterpene indole alkaloid biosynthesis. Chembio chem. 2019;20(1):83-87. https://doi.org/10.1002/cbic.201800592

56. Hoopes GM, Hamilton JP, Kim J, Zhao D, WiegertRininger K, Crisovan E, Buell CR. Genome Assembly and Annotation of the Medicinal Plant Calotropis gigantea, a Producer of Anticancer and Antimalarial Cardenolides. G3: Genes, Genomes, Genetics. 2018;8(2):385-91. https://doi.org/10.1534/g3.117.300331

57. Zhao D, Hamilton JP, Pham GM, Crisovan E, WiegertRininger K, Vaillancourt B. De novo genome assembly of Camptotheca acuminata, a natural source of the anticancer compound camptothecin. Gigascience. 2017;6(9):gix065. https://doi.org/10.1093/gigascience/gix065

58. Oshingboye AD, Ogundipe OT, Culham A. Direct Submission in NCBI; Department of Botany, University of Lagos, Molecular Systematics Laboratory, Akoka, Yaba, Lagos 23401, Nigeria. Submitted: 23-May-2016.

59. Gill A and Kaur R. Direct Submissionin NCBI; Botany, Punjabi University, Punjabi University Campus, Patiala, Punjab 147002, India. Submitted:17-Sep-2015.

60. Ndoye-Ndir K, Samb PI, Chevallier MH. Genetic variability analysis of the polyploid complex of Acacia nilotica (L.) Willd. Using RAPD markers. SOMMAIRE/INHOUD/SUMARIO.. 2008;26(3):135-40.

61. Misra A, Shukla AK, Shasany AK, Sundaresan V, Jain SP, Singh SC, et. al. AFLP markers for identification of Aconitum species. Med Aromat Plant Sci Biotechnol.2010;4:15-9.

62. Nayak D, Singh DR, Sabarinathan P, Singh S, Nayak T. Random amplified polymorphic DNA (RAPD) markers reveal genetic diversity in bael (Aegle marmelos Correa) genotypes of Andaman Islands, India. African Journal of Biotechnology. https://doi.org/10.5897/AJB2013.12473

63. Sheth BP and Thaker VS. Direct Submission in NCBI; Department of Biosciences, Saurashtra University, Rajkot, Gujarat 360005, India. Submitted: 20-Jan-2016.

64. Aparajita S, Rout GR. Genetic differentiation of Albizia lebbeck (L.) Benth. populations estimated by RAPD and ISSR markers. Plant Biosyst. 2009 Jul 1;143(2):361-8. https://doi.org/10.1080/11263500902722683 
65. Al-Zahim M, Newbury HJ, Ford-Lloyd BV. Classification of genetic variation in garlic (Allium sativum L.) revealed by RAPD. Hort Science. 1997;32(6):1102-04. https://doi.org/10.21273/HORTSCI.32.6.1102

66. Kress WJ, Wurdack KJ, Zimmer EA, Weigt LA, Janzen DH. Use of DNA barcodes to identify flowering plants. Proc Natl Acad Sci U S A. 2005 Jun 7;102:8369-74. https://doi.org/10.1073/pnas.0503123102

67. Sucher NJ, Carles MC. Genome-based approaches to the authentication of medicinal plants. Planta Med. 2008;74(06):603-23. $\quad$ https://doi.org/10.1055/s-20081074517

68. Ray T, Roy SC. Genetic diversity of Amaranthus species from the Indo-Gangetic plains revealed by RAPD analysis leading to the development of ecotype-specific SCAR marker. Journal of heredity. 2008;100(3):338-47. https://doi.org/10.1093/jhered/esn102

69. Mathew KM, Jose S, Rao YS, Gupta U, Thomas J. Optimization of genomic DNA extraction from fresh and dry leaves of large cardamom (Amomum subulatum Roxb.) for diversity analysis. Indian journal of biotechnology. 2014;13(2):221-4.

70. Malhotra SK. Plant genetic resources of seed spices in India. Seed Spices Newsletter 2003;3(1):1-4.

71. Feng T, Li Q, Wang Y, et. al. Phylogenetic analysis of Aquilaria Lam. (Thymelaeaceae) based on DNA barcoding. Holzforschung. 2008;73(6)517-24.

72. Wanke S, Jaramillo MA, Borsch T, Samain MS, Quandt D, Neinhuis C. Evolution of Piperales - matK gene and trnK intron sequence data reveal lineage specific resolution contrast. Mol Phylogenet Evol. 2007;42(2):477-97.

73. Vijay N, Sairkar P, Silawat N, Garg RK, Mehrotra NN. Genetic variability in Asparagus racemosus (Willd.) from Madhya Pradesh, India by random amplified polymorphic DNA. African Journal of Biotechnology. 2009;8(14).

74. Singh A, Chaudhury A, Srivastava PS, Lakshmikumaran M. Comparison of AFLP and SAMPL markers for assessment of intra-population genetic variation in Azadirachta indica A. Juss. Plant Science. 2002;162(1):1725. https://doi.org/10.1016/S0168-9452(01)00503-9ss

75. Darokar MP, Khanuja SP, Shasany AK, Kumar S. Low levels of genetic diversity detected by RAPD analysis in geographically distinct accessions of Bacopa monnieri. Genet Resour Crop Evol. 2001;48(6):555-8. https://doi.org/ 10.1023/A:1013800101604

76. Meenakshi K, Jamkhedkar S, George IA. Molecular profiling of some Barleria species using rbcL, matK gene sequences and RAPD markers. Journal of Applied Horticulture. 2016;18(3):203-206, 016.

77. Chen ZD, Yang T, Lin L, Lu LM, Li H, et. al.,, Direct Submission in NCBI; China Phylogeny Consortium, State Key Laboratory of Systematic and Evolutionary Botany, Institute of Botany, Chinese Academy of Sciences, No. 20 Nanxincun, Haidian District, Beijing 100093, P. R China. Submitted 11-JUL-2016; Tree of life for the genera of Chinese vascular plants; J Syst Evol. 2006;54 (4), 277-306.

78. Allen, JM, Germain-Aubrey CC, Barve N, Neubig KM, Majure LC, Laffan SW, et. al. Spatial Phylogenetics of Florida Vascular Plants: The Effects of Calibration and 243 Uncertainty on Diversity Estimates. iScience 2019;11: 57-70.

79. Padmalatha K, Prasad MN. Optimization of DNA isolation and PCR protocol for RAPD analysis of selected medicinal and aromatic plants of conservation concern from Peninsular India. African Journal of Biotechnology. 2006;5(3):230-4
80. Kandasamy TH, Kumari KA, Kaprakkaden AN, Lohot VD, Ghosh J. Molecular diversity analysis of flower colour variants of Butea monosperma (lam.) Taub using Inter Simple Sequence Repeats. Bioscan. 2013;8(3):969-74.

81. Gilmore S, Peakall R, Robertson J. Short tandem repeat (STR) DNA markers are hypervariable and informative in Cannabis sativa: implications for forensic investigations. Forensic sci int. 2003 ;131(1):65-74 https://doi.org/10.1016/S0379-0738(02)00397-3

82. Sheeba MS, Muneeb Hamza KH, Krishna Radhik N, Asha VV. Molecular diversities among Cardiospermum halicacabum Linn. populations in Kerala assessed using RAPD markers. Ann Phytomed. 2014;3(2):87-92.

83. Khan MA, von Witzke-Ehbrecht S, Maass BL, Becker HC. Relationships among different geographical groups, agro-morphology, fatty acid composition and RAPD marker diversity in safflower (Carthamus tinctorius). Genet Resour Crop Evol. 2009 Feb 1;56(1):19-30. https://doi.org/10.1007/s10722-008-9338-6

84. Raju NL, Prasad MN. Genetic diversity analysis of Celastrus paniculatus Willd. a nearly threatened, cognitive and intelligence enhancer by RAPD markers. Funct Plant Sci Biotechnol. 2007;1(1):195-99.

85. Ruas PM, Bonifacio A, Ruas CF, Fairbanks DJ, Andersen WR. Genetic relationship among 19 accessions of six species of Chenopodium L., by Random Amplified Polymorphic DNA fragments (RAPD). Euphytica. 1999;105(1):25-32. https://doi.org/10.1023/A:1003480414735

86. Sigmon BA, Adams RP, Mower JP. Complete chloroplast genome sequencing of vetiver grass(Chrysopogon zizanioides) identifies markers that distinguish nonfertile 'Sunshine' cultivar from other accessions. Ind Crops Prod 2017;108:629-35.

87. Swetha VP, Parvathy VA, Sheeja TE, Sasikumar B. DNA barcoding for discriminating the economically important Cinnamomum verum from its adulterants. Food biotechnol. 2014;28(3):183-94.

88. Lu L, Cox CJ, Mathews S, Wang W, et. al., Optimal data partitioning, multispecies coalescent and Bayesianconcordance analyses resolve early divergences of the grape family (Vitaceae); Cladistics (2017) In press. Direct Submission in NCBI; State Key Laboratory of Systematic and Evolutionary Botany, Institute of Botany, CAS, No. 20, Nanxincun, Xiangshan, Beijing, Beijing 100093, China. Submitted: 03-Oct-2016.

89. Yuan YW, Mabberley DJ, Steane DA, Olmstead RG. Further disintegration and redefinition of Clerodendrum (Lamiaceae): Implications for the understanding of the evolution an intriguing breeding strategy. Taxon. 2010;59(1):125-33.

90. Jarret RL, Merrick LC, Holms T, Evans J, Aradhya M. Simple sequence repeats in watermelon (Citrullus lanatus (Thunb.) Matsum. \& Nakai). Genome. 1997;40(4):433-41. https://doi.org/10.1139/g97-058

91. Pandey LK, Chatterjee V, Tripathi PK, et. al., DNA barcoding of Clitoria ternatea from Madhya Pradesh, India. Direct Submission in NCBI; Biotechnology, St. Aloysius College, AhilyaBai Marg, Sadar, Cantt, jabalpur, Madhya Pradesh 482001, India. Submitted :23-Nov-2017.

92. Moore MJ and Jansen RK. Molecular evidence for the age, origin, and evolutionary history of the American desert plant genus Tiquilia (Boraginaceae). Mol Phylogenet Evol. 2006;39(3):668-87. Direct Submission in NCBI; Florida Museum of Natural History, University of Florida, P. O. Box 117800, Gainesville, FL32611-7800, USA.Submitted:07-Sep-2005. 
93. Bhowmick BK, Nanda S, Nayak S, Jha S, Joshi RK. An APETALA3 MADS-box linked SCAR marker associated with male specific sex expression in Coccinia grandis (L). Voigt. Sci Hortic. 2014 Sep 11;176:85-90. https://doi.org/10.1016/i.scienta.2014.06.041

94. Govarthanan M, Arunapriya S, Selvankumar T, Selvam K. Genetic variability among Coleus sp. studied by RAPD banding pattern analysis. International Journal of Biotechnology and Molecular Biology Research. 2011;2(12):202-08. https://doi.org/10.5897/IJBMBR11.030

95. El-Nasr TH, Ibrahim MM, Aboud KA, El-Enany MA. Assessment of genetic variability for three coriander (Coriandrum sativum L.) cultivars grown in egypt, using morphological characters, essential oil composition and ISSR Markers. World Applied Sciences Journal. 2013;25:839-49.

96. Mandal AB, Thomas VA. RAPD pattern of Costus speciosus Koen ex. Retz., an important medicinal plant from the Andaman and Nicobar. Curr Sci. 2007;93(3):369-73.

97. Kim YH, Shin YH, Kang SH, Kim JH, Ko SC. Relationship of Lycoris (Amaryllidaceae) based on RAPD markers. Korean Journal of Plant Taxonomy. 2008;38(1):17-29. https://doi.org/10.11110/kjpt.2000.30.1.017

98. Caiola MG, Caputo P, Zanier R. RAPD analysis in Crocus sativus L. accessions and related Crocus species. Biologia Plantarum. 2004;48(3):375-80. https://doi.org/10.1023/B:BIOP.0000041089.92559.84

99. Van Ee BW, Forster PI, Berry PE. Phylogenetic relationships and a new sectional classification of Croton (Euphorbiaceae) in Australia. Aust syst bot. 2015;28(4):219-33.

100. Horejsi T, Staub JE. Genetic variation in cucumber (Cucumis sativus L.) as assessed by random amplified polymorphic DNA. Genet Resour Crop Evol. 1999;46(4):337-50. https://doi.org/10.1023/A:1008650509966

101. Bahraminejad A, Mohammadi-Nejad G, Abdul Kadir K, Bin Yusop MR, Samia MA. Molecular diversity of Cumin (Cuminum cyminum L.) using RAPD markers. Aust J Crop Sci. 2012;6(2):194-99.

102. Sasikumar B, Syamkumar S, Remya R, John Zachariah T. PCR based detection of adulteration in the market samples of turmeric powder. Food Biotechnol. 2004;18(3):299-306. $\quad$ https://doi.org/10.1081/FBT200035022

103. Pathak R, Singh SK, Singh M, Henry A. Molecular assessment of genetic diversity in cluster bean (Cyamopsis tetragonoloba) genotypes. Journal of Genetics. https://doi.org/10.1007/s12041-010-0033-y

104. Liede-Schumann S, Dötterl S, Gebauer M, Meve U. A RAPD study of the Sarcostemma group of Cynanchum (Apocynaceae - Asclepiadoideae - Asclepiadeae). Org Divers Evol. 2013;13(1):15-31.

105. Roodt R, Spies JJ, Burger TH. Preliminary DNA fingerprinting of the turf grass Cynodondactylon (Poaceae: Chloridoideae). Bothalia.2002;32(1):117-22. https://doi.org/10.4102/abc.v32i1.474

106. Arif M, Zaidi NW, Singh YP, Haq QM, Singh US. A comparative analysis of ISSR and RAPD markers for study of genetic diversity in Shisham (Dalbergia sissoo). Plant Mol Biol Report. 2009;27(4):488-95. https://doi.org/10.1007/s11105-009-0097-0

107. Parani M, Lakshmi M, Senthilkumar P, Ram N, Parida A. Molecular phylogeny of mangroves V. Analysis of genome relationships in mangrove species using RAPD and RFLP markers. Theor Appl Genet. 1998;97(4):617-25. https://doi.org/10.1007/s001220050937

108. Sukrong S, Phadungcharoen T, Ruangrungsi N. DNA fingerprinting of medicinally used Derris species by RAPD molecular markers. Planta Med. 2006;72(11):P_162. https://doi.org/10.1055/s-2006-949962

109. Irshad S, Singh J, Kakkar P, Mehrotra S. Molecular characterization of Desmodium species - An important ingredient of 'Dashmoola' by RAPD analysis. Fitoterapia. 2009 Mar 1;80(2):115-8. https://doi.org/10.1016/j.fitote.2008.11.004

110. Nebauer SG, del Castillo-Agudo L, Segura J. An assessment of genetic relationships within the genus Digitalis based on PCR-generated RAPD markers. Theor Appl Genet. 2000;100(8):1209-16. $\quad$ https://doi.org/ $\underline{10.1007 / \mathrm{s} 001220051426}$

111. Ramser J, Weising K, Kahl G, López-Peralta C, Wetzel R. Genomic variation and relationships in aerial yam (Dioscorea bulbifera L.) detected by random amplified polymorphic DNA. Genome. 1996 ;39(1):17-25 https://doi.org/10.1139/g96-003

112. Jehan T, Vashishtha A, Yadav SR, Lakhanpaul S. Genetic diversity and genetic relationships in Hyacinthaceae in India using RAPD and SRAP markers. Physiol Mol Biol Plants. 2014;20(1):103-14. https://doi.org/10.1007/s12298013-0206-2

113. Moraes MD. Taxonomia e filogenia e dimerostemma, e sua relação intergenerica na subtribo Ecliptinae (Asteraceae: Heliantheae).2004.

114. Balasubramani SP, Manjunatha R, Venkatasubramanian P. et. al., Draft Genome of Embelia ribes. Direct Submission in NCBI; School of Life Sciences, Transdisciplinary University, FRLHT, \#74/2, Jarakabande Kava, Bangalore, Karnataka 560106, India. Submitted:26-Sep-2016.

115. Keil M, Griffin AR. Use of random amplified polymorphic DNA (RAPD) markers in the discrimination and verification of genotypes in Eucalyptus. Theor Appl Genet. 1994;89(4):442-50.

116. Raju BS, Manoj K, Sahoo D. Assessment of genetic diversity of Ficusspecies using RAPDmarkers as a measure of genomic polymorphism. IOSR J Pharm Biol Sci. 2015;10(1):22-7.

117. Zhang LF, Zhang Z, Wang XM, GAO H, Tian HZ, Li HQ. Molecular Phylogeny of the Ficus auriculata Complex (Moraceae). Phytotaxa. 2018;362(1):039-54.

118. Al-Juhani WS. DNA barcoding of flora Saudi Arabia; Direct Submissionin NCBI; Biology, Umm Al-Qura University, Al Zaher, Makkah, Westren region 2360, Saudi Arabia. Submitted :16-Jun-2018.

119. Thulin M, Moore AJ, El-Seedi H, Larsson A, Christin PA, Edwards EJ. Phylogeny and generic delimitation in Molluginaceae, new pigment data in Caryophyllales, and the new family Corbichoniaceae. Taxon. 2016;65(4):77593.

120. Sabir J, Schwarz E, Ellison N, Zhang J, Baeshen NA, Mutwakil M, Jansen R, Ruhlman T. Evolutionary and biotechnology implications of plastid genome variation in the inverted repeat lacking clade of legumes. Plant biotechnol J. 2014;(6):743-54.

121. Liu D, Guo X, Lin Z, Nie Y, Zhang X. Genetic diversity of Asian cotton (Gossypium arboreum L.) in China evaluated by microsatellite analysis. Genet Resour Crop Evol. https://doi.org/10.1007/s10722-005-1304-y 
122. Kumar KS, Maruthi KR, Alfarhan AH, Rajakrishnan R, Thomas J. Molecular fingerprinting of Helicanthus elastica (Desr.) Danser growing on five different hosts by RAPD. Saudi J Biol Sci. 2016 ;23(3):335-40. https://doi.org/ 10.1016/j.sjbs.2015.12.002

123. Sanchez Puerta MV, Zubko MK, Palmer JD. Homologous recombination and retention of a single form of most genes shape the highly chimeric mitochondrial genome of a cybrid plant. New Phytol. 2015;206(1):381-96.

124. Zhang N and Handy SM. Plastid Genomes of Illicium; (Unpublished). Direct Submissionin NCBI; Center of Food Safety and Nutrition, Food and Drug Adminstration, 5100 Paint Branch Pkwy, College Park, MD 20740, USA. Submitted:31-Oct-2016.

125. Rajaseger G, Tan HT, Turner IM, Saw LG, Kumar PP. Random amplified polymorphic DNA variation among and within selected Ixora (Rubiaceae) populations and mutants. Ann Bot. 1999;84(2):253-57. https://doi.org/10.1006/anbo.1999.0918

126. Gupta S, Srivastava M, Mishra GP, Naik PK, Chauhan RS, Tiwari SK, Kumar M, Singh R. Analogy of ISSR and RAPD markers for comparative analysis of genetic diversity among different Jatropha curcas genotypes. African Journal of Biotechnology. 2008;7(23).

127. Kiel CA, Daniel TF, Darbyshire I, McDade LA. Unraveling relationships in the morphologically diverse and taxonomically challenging. Taxon. 2017;66(3):645-74.

128. Techaprasan J, Klinbunga S, Ngamriabsakul C, Jenjittikul T. Genetic variation of Kaempferia (Zingiberaceae) in Thailand based on chloroplast DNA (psbA-trnH and petA-psbJ) sequences.Genet Mol Res. 2010;9(4):1957-73. https://doi.org/10.4238/vol9-4gmr873

129. Kumar SU, Goyal RA, Sheorayan AR, Kajla SU, Yadav OP, Mangal MA. Assessment of genetic diversity in Lepidium sativum using RAPD and ISSR markers. Ann Biol. 2012;28:93-97.

130. Sanjana P, Cordilea Hannah S, Senthilkumar U. Molecular phylogeny of selected species Genus Leucas from Peninsular India using DNA barcodes; (Unpublished). Direct Submission in NCBI; Department of Plant Biology and Plant Biotechnology, Women's Christian College, College Road, Chennai, Tamil Nadu 600006, India.Submitted05-Apr-2018.

131. Oh TJ, Gorman M, Cullis CA. RFLP and RAPD mapping in flax (Linum usitatissimum). Theor Appl Genet. 2000;101(4):590-3. https://doi.org/10.1007/s001220051520

132. Gavankar R, Chemburkar M. Genetic analysis of Madhuca longifolia (J. Koenig ex L.) JF Macbr. using RAPD markers. Int J Curr Microbiol App Sci. 2016;5(8):608-15. https://doi.org/10.20546/ijcmas.2016.508.068

133. Borchsenius F, Suarez LSS, Prince LM. Molecular phylogeny and redefined generic limits of Calathea (Marantaceae). Syst Bot. 2012;37(2):620-635.

134. Zhang D. Direct Submissionin NCBI; Guangdong Provincial Hospital of ChineseMedicine, leaves, guoyi, guangzhou, guangdong 510000, China.Submitted :02-Jul2018.

135. Drew BT, Sytsma KJ. Phylogenetics, biogeography, and staminal evolution in the tribe Mentheae (Lamiaceae). Am J Bot. 2012;99(5):933-53.

136. Zhu S. The identification and prewarning of invasive plants in Guangzhou based on DNA barcoding;. Direct Submissionin NCBI; Botany, South China Botanical Garden, No.723, Xingke Road, Tianhe District, Guangzhou, Guangdong 510650,China.Submitted:13Mar-2018.
137. Muluvi GM, Sprent JI, Soranzo N, Provan J, Odee D, Folkard G, McNicol JW, Powell W. Amplified fragment length polymorphism (AFLP) analysis of genetic variation in Moringa oleifera Lam. Mol Ecol. 1999;8(3):463-70. 294X.1999.00589.x

138. Saini RK, Saad KR, Ravishankar GA, Giridhar P, Shetty NP. Genetic diversity of commercially grown Moringa oleifera Lam. cultivars from India by RAPD, ISSR and cytochrome P 450-based markers. Plant Syst Evol. 2013;299(7):1205-13. https://doi.org/10.1007/s00606-013-0789-7

139. Capo-Chichi LJ, Morton CM, Weaver DB. An intraspecific genetic map of velvetbean (Mucuna sp.) based on AFLP markers. Theor Appl Genet. 2004;108(5):814-21. https://doi.org/10.1007/s00122-003-1493-8

140. Padmesh P, Reji JV, Dhar MJ, Seeni S. Estimation of genetic diversity in varieties of Mucuna pruriens using RAPD. Biologia Plantarum. 2006;50(3):367-72. https:// doi.org/10.1007/s10535-006-0051-Z

141. Staats M and Fronen B. DNA barcoding of herbs and spices, and other condiments.Direct Submission. RIKILT -WUR, Wageningen University, Akkermaalsbos 2, Wageningen 6708 WB, Netherlands Submitted; 27-Jul2018.

142. Brown N, Venkatasamy S, Khittoo G, Bahorun T, Jawaheer S. Evaluation of genetic diversity between 27 banana cultivars (Musa spp.) in Mauritius using RAPD markers. African Journal of Biotechnology. 2009;8(9).

143. Yanthan M, Misra AK. Molecular approach to the classification of medicinally important actinorhizal genus Myrica. Indian Journal of Biotechnology. 2013;12:133-6.

144. Swetha VP, Parvathy VA, Sheeja TE, Sasikumar B. Authentication of Myristica fragrans Houtt. using DNA barcoding. Food Control. 2017;73:1010-5.

145. Singh UM, Yadav D, Tripathi MK, Kumar A, Yadav MK. Genetic diversity analysis of Nardostachys jatamansi DC, an endangered medicinal plant of Central Himalaya, using random amplified polymorphic DNA (RAPD) markers. African Journal of Biotechnology. 2013;12(20): 2816-21.

146. Iqbal MS, Nadeem S, Mehboob S, Ghafoor A, Rajoka MI, Qureshi AS, Niaz B. Exploration of genotype specific fingerprinting of Nigella sativa L. using RAPD markers. Turk J Agric For. 2011;35(6):569-78.

147. Rabah SO, Shrestha B, Hajrah NH, Sabir MJ, Alharby HF, Sabir MJ, Alhebshi AM, Sabir JS, Gilbert LE, Ruhlman TA, Jansen RK. Passiflora plastome sequencing reveals widespread genomic rearrangements. J syst evol. 2019;57(1):1-4.

148. Carovic K, Liber Z, Javornik B, Kolak I, Satovic Z. Genetic relationships within basil (Ocimum) as revealed by RAPD and AFLP markers. In XXVII International Horticultural Congress-IHC2006: II International Symposium on Plant Genetic Resources of Horticultural. 2006;171-78. https://doi.org/10.17660/ActaHortic.2007.760.22

149. Stefanovic S, Krueger L, Olmstead RG. Monophyly of the Convolvulaceae and circumscription of their major lineages based on DNA sequences of multiple chloroplast loci. Am J Bot. 2002; 89(9):1510-22.

150. Yang M, Zhang X, Liu G, Yin Y, Chen K, Yun Q, et. al., The complete chloroplast genome sequence of date palm (Phoenix dactylifera L.). PLoS One. 2010;5(9):e12762.

151. Kafkas S, Perl-Treves R. Interspecific relationships in Pistacia based on RAPD fingerprinting. Hort Science. 
2002;37(1):168-71. https://doi.org/10.21273/HORTSCI.37.1.168

152. Hu JY, Saedler H. Evolution of the inflated calyx syndrome in Solanaceae; Mol Biol Evol. 2007;24 (11), 2443-53. Direct Submission in NCBI; Molecular Plant Genetics, Max-Planck-Institute for Plant Breeding Research, Carl-von-Linne weg 10, Koeln 50829, Germany. Submitted:14-Feb-2007.

153. Patra AP, Mukherjee AK, Acharya L. Comparative study of RAPD and ISSR markers to assess the genetic diversity of betel vine (Piper betle L.) in Orissa, India. Am J Biochem Mol Biol. 2011;1:200-11. https://doi.org/10.3923/ ajbmb.2011.200.211

154. Khan S, Mirza KJ, Anwar F, Abdin MZ. Development of RAPD markers for authentication of Piper nigrum (L.). Environment \& We an International

Journal of Science \& Technology. 2010;5:47-56.

155. El-hawary SS, El-sofany RH, Abdel-Monem AR, Ashour RS. Phytochemical Screening, DNA Fingerprinting, and Nutritional Value of Plectranthus amboinicus (Lour.) Spreng. Pharmacognosy Journal. 2012;4(30):10-3. https:// doi.org/10.5530/pj.2012.30.2

156. Koutroumpa $\mathrm{K}$, Theodoridis $\mathrm{S}$, Warren $\mathrm{BH}$, et. al., An expanded molecular phylogeny of Plumbaginaceae, with emphasis on Limonium (sea lavenders): Taxonomic implications and biogeographic considerations; Ecol Evol 2018;8 (24), 12397-424.

157. Kesari V, Rangan L. Genetic diversity analysis by RAPD markers in candidate plus trees of Pongamia pinnata, a promising source of bioenergy. Biomass Bioenergy. 2011 Jul https://doi.org/10.1016/j.biombioe.2011.04.015 1;35(7):3123-28

158. Sharma SK, Rawat D, Kumar S, Kumar A, Kumaria S, Satyawada RR. Single primer amplification reaction (SPAR) reveals intra-specific natural variation in Prosopis cineraria (L.) Druce. Trees. 2010;24(5):855-64. https://doi.org/10.1007/s00468-010-0455-4

159. Elmeer K, Almalki A. DNA finger printing of Prosopis cineraria and Prosopis juliflora using ISSR and RAPD techniques. Am J Plant Sci. 2011;2(04):527.

160. Jhansi Rani S, Usha R. Development of rapd and specific scar markers for the identification of Pterocarpus santalinus. L. Journal of Cell and Tissue Research. 2013;13(3). https://doi.org/10.4236/ajps.2011.24062

161. Song XY, Liu LW, Gong YQ, Wang MX, Zhao LP, Huang DQ. Optimization of RAPD and ISSR-PCR Reaction Systems for Radish (Raphanus sativus L.) Genomic DNA (J). Seed. 2007;2.

162. Padmalatha K, Prasad MN. Inter and intra-population genetic diversity of Rauvolfia serpentina (L.) Benth. ex Kurz, an endangered medicinal plant, by RAPD analysis. Med Aromat Plant Sci Biotechnol. 2007;1(1):118-23.

163. Allan G, Williams A, Rabinowicz PD, Chan AP, Ravel J, Keim P. Worldwide genotyping of castor bean germplasm (Ricinus communis L.) using AFLPs and SSRs. Genet Resour Crop Evol. 2008;55(3):365-78. https://doi.org/10.1007/s10722-007-9244-3

164. Khan S, Mirza KJ, Tyagi MR, Abdin MZ. Development of RAPD markers for authentication of Ruta graveolens (L) and its adulterant. MAPSB. 2011;5(1):58-61.

165. Al-Qurainy F, Khan S, Tarroum M, Al-Hemaid FM, Ali MA. Molecular authentication of the medicinal herb Ruta graveolens (Rutaceae) and an adulterant using nuclear and chloroplast DNA markers. Genet Mol Res. 2011;10(4):2806-16.

https://doi.org/10.4238/2011.November.10.3
166. Asano T, Tsudzuki T, Takahashi S, Shimada H, Kadowaki KI. Complete nucleotide sequence of the sugarcane (Saccharum officinarum) chloroplast genome: a comparative analysis of four monocot chloroplast genomes. DNA research. 2004;11(2):93-99.

167. Mahar KS, Rana TS, Ranade SA. Molecular analyses of genetic variability in soap nut (Sapindus mukorossi Gaertn.). Industrial crops and products. 2011;34(1):111118. https://doi.org/10.1016/j.indcrop.2011.03.029

168. Weeks A, Zapata F, Pell SK, Daly DC, Mitchell JD, Fine PV. To move or to evolve: contrasting patterns of intercontinental connectivity and climatic niche evolution in "Terebinthaceae"(Anacardiaceae and Burseraceae). Front Genet. 2014;5:409. https://doi.org/10.3389/fgene.2014.00409

169. Yi DK, Kim KJ. Complete chloroplast genome sequences of important oilseed crop Sesamum indicum L. PloS one. 2012;7(5):e35872.

https://doi.org/10.1371/journal.pone.0035872

170. Farruggia FT. Phylogenetic and monographic studies of the pantropical genus Sesbania Adanson (Leguminosae). Arizona State University; 2009.

171. Kumar JS, Krishna V, Seethapathy GS, Senthilkumar U, Ragupathy S, Ganeshaiah KN, Ganesan R, Newmaster SG, Ravikanth G, Shaanker RU. DNA barcoding to assess species adulteration in raw drug trade of "Bala"(genus: Sida L.) herbal products in South India. Biochem syst ecol. 2015;61:501-9.

172. Rosario LH, Padilla JO, Martínez DR, Grajales AM, Reyes JA, Feliu GJ, Van Ee B, Siritunga D. DNA Barcoding of the Solanaceae Family in Puerto Rico Including Endangered and Endemic Species. J Am Soc Hortic Sci. 2019;144(5):363-74. https://doi.org/10.21273/JASHS0473519

173. Levin RA, Watson K, Bohs L. A four-gene study of evolutionary relationships in Solanum section Acanthophora. Am J Bot. 2005;92(4):603-12. https://doi.org/10.3732/ajb.92.4.603

174. Chiarini FE, Scaldaferro MA, Bernardello G, Acosta MC. Cryptic genetic diversity in Solanum elaeagnifolium (Solanaceae) from South America. Aust J Bot 2018;66(7):531-40. https://doi.org/10.1071/BT17245

175. Rosario LH, Padilla JO, Martínez DR, Grajales AM, Reyes JA, Feliu GJ, Van Ee B, Siritunga D. DNA Barcoding of the Solanaceae Family in Puerto Rico Including Endangered and Endemic Species. J Am Soc Hortic Sci. 2019;144(5):363-74. https://doi.org/10.21273/JASHS04735$\underline{19}$

176. de la Estrella M, Forest F, Klitgard B, Lewis GP, Mackinder BA, et. al., A new phylogeny-based tribal classification of subfamily Detarioideae, an early branching clade of florally diverse tropical arborescent legumes. Scientific Reports. 2018;8(1):6884. https://doi.org/10.1038/s41598-018-24687-3

177. Collins D, Mill RR, Möller M. Species separation of Taxus baccata, T. canadensis, and T. cuspidata (Taxaceae) and origins of their reputed hybrids inferred from RAPD and cpDNA data. Am J Bot. 2003;90(2):175-82. https://doi.org/10.3732/ajb.90.2.175

178. Bhau BS, Negi MS, Jindal SK, Singh M, Lakshmikumaran M. Assessing genetic diversity of Tecomella undulata (Sm.) Seem. - An endangered tree species using amplified fragment length polymorphisms-based molecular markers. Curr Sci. 2007;67-72.

179. Lakshmi P, Khan PA, Reddy PN, Lakshminarayana K, Ganapaty S. Genetic relationship among Tephrosia species as revealed by RAPD analysis. Asian Journal of 
Biological Science. 2008;1(1):1-10. https://doi.org/10.3923/ ajbs.2008.1.10

180. Sarwat M, Das S, Srivastava PS. Estimation of genetic diversity and evaluation of relatedness through molecular markers among medicinally important trees: Terminalia arjuna, T. chebula and T. bellerica. Mol Biol Rep. 2011;38(8):5025-36. https://doi.org/10.1007/s11033010-0649-2

181. Shinde VM, Dhalwal K, Mahadik KR, Joshi KS, Patwardhan BK. RAPD analysis for determination of components in herbal medicine. J Evid Based Complementary Altern Med. 2007;4(S1):21-3. https://doi.org/10.1093/ecam/nem109

182. Tomar P, Malik CP. Genetic diversity assessment in Trachyspermum ammi L. Sprague using CDDP and CBDP markers. Journal of Plant Science Research. 2016;32(1):27-36

183. Sarwat M, Das S, Srivastava PS. Analysis of genetic diversity through AFLP, SAMPL, ISSR and RAPD markers in Tribulus terrestris, a medicinal herb. Plant Cell Rep. 2008;27(3):519-28. https://doi.org/10.1007/s00299-007-0478-5

184. Seneviratne G. Female sex-associated RAPD marker in pointed gourd (Trichosanthes dioica Roxb.). Curr Sci. 2002;82(2):131.

185. Li XJ, Fan CZ. Medicinal Materials Department, injiang Institute of Chinese Traditional Medical and Ethical Materia Medica, 9 Xinming Road, Urumqi, Xinjiang 830002, China. Submitted:25-Jul-2013.

186. Aras S, Duran A and Yenilmez G. Isolation of DNA for RAPD analysis from dry leaf material of some Hesperis L. specimens. Plant Mol Biol Rep.1993;21:461a-461f. https:// doi.org/10.1007/BF02772597

187. Vanijajiva O, Sirirugsa $\mathrm{P}$ and Suvachittanont W. Confirmation of relationships among Boesenbergia (Zingiberaceae) and related genera by RAPD. Biochem Syst Ecol. 2005;33:159-70. https://doi.org/10.1016/j.bse.2004.06.012

188. Techen N, Khan IA, Pan Z, Scheffler BE. The use of polymerase chain reaction (PCR) for the identification of Ephedra DNA in dietary supplements. Planta Med. 2006; 72:241-47. https://doi.org/10.1055/s-2005-916173

189. Seethapathy GS, Raclariu-Manolica AC, Anmarkrud JA, Wangensteen $\mathrm{H}$, De Boer HJ. DNA metabarcoding authentication of Ayurvedic herbal products on the European market raises concerns of quality and fidelity. Front Plant $\quad$ Sci. 2019;10:68. https://doi.org/10.3389/fpls.2019.00068

190. Li Q, Sun Y, Guo H, Sang F, Ma H, Peng H, et. al., Quality control of the traditional Chinese medicine Ruyijinhuang powder based on high-throughput sequencing and realtime PCR. Sci Rep. 2018;8. https://doi.org/10.1038/s41598018-26520-3

191. Choo BK, Moon BC, Ji Y, Kim BB, et. al., Development of SCAR markers for the discrimination of three species of medicinal plants, Angelica decursiva (Peucedanum decursivum), Peucedanum praeruptorum and Anthricus sylvestris, based on the internal transcribed spacer (ITS) sequence and random amplified polymorphic DNA (RAPD). Biol Pharm Bull. 2008:32:24-30. https://doi.org/10.1248/bpb.32.24

192. Jones CJ, Edwards KJ, Castaglione S, Winfield MO, Sala F, Van de Wiel C, Bredemeijer G, Vosman B, Matthes M, Daly A, Brettschneider R. Reproducibility testing of RAPD, AFLP and SSR markers in plants by a network of European laboratories. Mol breed. 1997;3(5):381-90. https://doi.org/10.1023/A:1009612517139

193. Kerr KC, Stoeckle MY, Dove CJ, Weigt LA, Francis CM, Hebert PD. Comprehensive DNA barcode coverage of North American birds. Mol Ecol Notes. 2007;7(4):535-43. https://doi.org/10.1111/j.1471-8286.2007.01670.x

194. Singh HK, Parveen I, Raghuvanshi S, Babbar SB. The loci recommended as universal barcodes for plants on the basis of floristic studies may not work with congeneric species as exemplified by DNA barcoding of Dendrobium species. BMC Res Notes. 2012;5(1):42. https://doi.org/10.1186/1756-0500-5-42

195. Roy S, Tyagi A, Shukla V, Kumar A, Singh UM, Chaudhary LB, Datt B, Bag SK, Singh PK, Nair NK, Husain T. Universal plant DNA barcode loci may not work in complex groups: a case study with Indian Berberis species. PLoS One. 2010;5(10):e13674. https://doi.org/10.1371/journal.pone.0013674

196. Dubey NK, Kumar R, Tripathi P. Global promotion of herbal medicine: India's opportunity. Curr Sci. 2004;86:37-41.

197. Zhang X, World Health Organization (WHO). General guidelines for methodologies on research and evaluation of traditional medicine. World Health Organization. 2000:1-71.

198. Yan-Bo Z, Pang-Chui S, Cho-Wing S, Zheng-Tao W, Yao T. Molecular authentication of Chinese herbal materials. J Food Drug Anal. 2007;15:1-9.

199. Echeverrigaray S, Agostini G, Atti-Serfini L, Paroul N, Pauletti GF, dos Santos AC. Correlation between the chemical and genetic relationships among commercial thyme cultivars. J Agric Food Chem. 2001;49: 4220-23. https://doi.org/10.1021/jf010289j

200. Chan K. Some aspects of toxic contaminants in herbal medicines. Chemosphere. 2013;52: 1361-71. https://doi.org/10.1016/S0045-6535(03)00471-5

201. Yip PY, Chau CF, Mak CY, Kwan HS. DNA methods for identification of Chinese medicinal materials. Chin Med.2007;2:9. https://doi.org/10.1186/1749-8546-2-9

202. Mahajan RTCM. Phyto-pharmacology of Ziziphus jujuba Mill a plant review. Pharmacol Rev. 2009;320-29.

203. Commission TBP. Appendix XI V. Deoxyribonucleic Acid (DNA) Based Identification Techniques for Herbal Drugs. (London: Te British Pharmacopoeia Commission, 2015). 